\title{
ABORDĂRI PARADIGMATICE ÎN DETERMINAREA PROFILULUI FORMATORULUI DE SUCCES
}

\author{
Delia-Mariana ARDELEAN*
}

\author{
Paradigmatic approaches to profiling successful trainer
}

\begin{abstract}
The rationale behind the choice of this theme started from a debate with training program beneficiaries and their trainers on "the optimal profile of trainers". Their descriptions of the investigated phenomenon refer to features within the registry factors highlighted by the psychological literature, namely: personality characteristics, expertise in scientific content (what is taught) as well as pedagogical expertise. The second reason for choosing this subject is the fact that psychology literature and organizational work does not provide too much data to support the objective. Naturally, this aspect raises the challenge of researching those factors that compose the optimal profile of the trainer and identifying the best method of data collection, ie, their interpretation, and then, furthermore, the challenge of reaching some conclusions/outlining future actions designed to improve the trainers' performance, at least in the Romanian culture.
\end{abstract}

Keywords: learning, teacher, student, training, trainer, personality, knowledge, effectiveness of a training program

\section{Introducere}

Studiul de față are drept scop identificarea, evaluarea şi managementul variabilelor care influenţează eficienţa unui program de formare profesională destinat cadrelor didactice și implicit, adulţilor prin parcurgerea literaturii de specialitate pentru a identifica care sunt factorii care alcătuiesc profilul optim al formatorului de succes. Pornind de la datele prezentate în studiile parcurse și prezentate, pe scurt, în secţiunea destinată fundamentării teoretice, ne vom îndrepta atenţia, în articolul de faţă, asupra modului în care diferite grupuri de respondenţi (novici şi experţi în domeniul formării profesionale a adulţilor) descriu profilul optim al formatorului, identificând eventuale suprapuneri între răspunsurile specifice contextului de cercetare românesc şi cele specifice culturii vestice/în special, americane. În acest sens, vom utiliza analiza de conţinut și prelucrările statistice descriptive.

Apoi pe baza unei metaanalize cantitative pentru identificarea factorilor relevanţi care determină eficienţa unui program de formare

\footnotetext{
* Conf. univ. dr., Universitatea de Vest „Vasile Goldiș” Arad, Facultatea de Științe SocioUmane și Educaţie Fizică și Sport, Centrul Județean de Resurse și Asistenţă Educaţională Maramureș, Str. 8 Martie, Nr. 7, 430406, Baia Mare (deliamarianaardelean@yahoo.com).
} 
profesională, în cazul unui public ţintă format din adulţi, ne propunem să dezvoltăm un model comprehensiv al factorilor care determină eficienţa unui program de formare profesională a adulţilor şi să îi testăm eficienţa, astfel încât să surprindem efectul cât mai acurat al acestor factori asupra transferului competenţelor dobândite în formare, la nivelul mediului de muncă.

Menţionăm că până acum, nu am identificat studii care să trateze profilul optim al formatorului, motiv pentru care ne-am îndreptat atenţia spre sfera psihologiei educaţionale, acest domeniu furnizând o bază de date mai variată cu privire la acest subiect. Nici aici nu se precizează foarte clar factorii care stau la baza alcăturii profilului optim al cadrului didactic, studiile conduse pe marginea acestui subiect reliefând mai multe variabile precum: factorii de personalitate, cunoştinţele specifice domeniului predării sau cele de natură psihopedagogică (Towler şi Dipboye, 2006).

\section{Motivația alegerii temei}

Motivaţia care a stat la baza alegerii acestei teme a pornit de la o simplă discuţie cu beneficiarii unui program de formare profesională sau cu formatorii despre "profilul optim al formatorului". Descrierile lor asupra fenomenului investigat implică caracteristici din acelaşi registru cu factorii reliefaţi de literatura de specialitate, şi anume: caracteristici de personalitate, expertiză în domeniul de conţinut al materiei predate şi expertiză psihopedagogică. Cel de-al doilea motiv pentru alegerea acestui subiect este dat de faptul că literatura din domeniul psihologiei muncii şi organizaţionale nu oferă prea multe date care să vină în sprijinul obiectivului propus. În mod firesc, datorită acestui lucru, se naşte provocarea de a studia factorii care alcătuiesc profilul optim al formatorului şi de a identifica cea mai bună metodă de culegere a datelor, respectiv, de interpretare a lor, pentru ca apoi, să desprindem o serie de concluzii/direcţii de acţiune menite să îmbunătăţească prestaţia formatorilor, cel puţin în mediul cultural românesc.

\section{Fundamentarea teoretică}

Pentru a putea fundamenta teoretic necesitatea conducerii acestui studiu, vom porni de la a defini conceptele cu care vom opera. Apoi, vom prezenta asumpţiile principalelor paradigme ale învăţării şi rolul profesorului în fiecare dintre acestea, urmând să o alegem pe cea care este mai potrivită pentru a propune un transfer paradigmatic dinspre rolul profesorului, spre cel al formatorului. În final, vom demara cercetarea investigând percepţiile respondenţilor asupra factorilor care alcătuiesc profilului optim al formatorului, prin lentila paradigmatică considerată a fi cea mai potrivită.

Pentru început ne propunem să clarificăm conceptele cu care vom opera în continuare: învăţare, profesor, cursant, formare profesională, 
formator, personalitate, cunoştinţe, eficienţa unui program de formare profesională.

Primele trei concepte-cheie vor fi definite din perspectiva principalelor paradigme ale învăţării, urmând ca restul conceptelor, să fie prezentate din perspectiva autorilor care cercetează profilul optim al profesorului şi impactul acestui profil asupra performanţei elevilor/ studenților la clasă/ an de studiu. Apoi, vom încerca să facem o comparaţie între definiţia profesorului și cea a formatorului, stabilind asemănările şi diferenţele între cei doi, pentru a trece mai departe la clarificarea următoarelor concepte cu care vom opera.

Principalele paradigme ale învăţării care s-au impus în studiile vremii au fost paradigma psihanalistă, paradigma behavioristă, cea cognitivistă, umanistă şi paradigma constructivistă (cu variaţiunea socio-constructivistă). În continuare, vom prezenta asumpţiile acestor paradigme şi modul în care, acestea definesc învăţarea, rolul profesorului şi cel al elevului/studentului/ respectiv al cursantului, în procesul de învățare.

Psihanaliştii văd fiinţa umană ca fiind în natura sa negativă, manifestând comportamente cu scopul de a obţine plăcere (David, 2006). Conform acestei abordări, elevii/studenții/cursanţii nu doresc să înveţe noi comportamente sau să se dezvolte. Din acest motiv, profesorul este acea persoană care trebuie să exercite o presiune susţinută asupra rezistenţei la schimbare manifestate de către elev/student/cursant, cu scopul de a-1 determina pe acesta să identifice şi să controleze modalităţile prin care inconştientul/pulsiunile pot influenţa gândirea şi comportamentul. Identificarea şi managementul pulsiunilor de căutare a plăcerii reprezintă învăţarea.

Behaviorismul defineşte învăţarea ca pe o schimbare vizibilă în comportamentul elevului/studentului/cursantului (Opre, 2003). Părinţii behaviorismului (Pavlov, Watson, Skinner, Gagné, Thorndike) afirmă că învăţarea are loc prin repetarea noilor modele de comportament până la producerea automatizării. Behavioriștii subliniază rolul contextului în care are loc învăţarea, comportamentul nou produs fiind determinat şi menţinut de întăririle primite (Amstrong, 2006). Elevul/studentul/cursantul reproduce cunoştinţele transmise de profesor, rolul dascălului fiind acela de a determina stimulii şi întăririle care vor duce la răspunsul dorit, de a asigura condiţiile propice de mediu pentru a avea loc învăţarea. Învăţarea şi responsabilitatea învăţării sunt centrate pe profesor.

Umaniştii arată prezenţa potenţialului de învăţare în fiecare fiinţă, cu sopul de a răspunde tendinţei organismului de a se actualiza continuu (Rogers, în Opre, 2003). Din această perspectivă, elevul/studentul/cursantul este individul care are în permanenţă nevoia de a se actualiza, rolul profesorului fiind acela de a-1 ajuta pe acesta să îşi conştientizeze această nevoie. Mai mult, profesorul trebuie să identifice şi să accepte existenţa 
unor diferenţe între elevi/studenţi/cursanţi, să pornească de la experienţa acestora de viaţă, să o valorizeze, să ofere feedback constructiv, să empatizeze, astfel încât să determine o învăţare bazată pe colaborarea dintre profesor şi cursant, autodirecţionată şi nu dependentă de el. Din această perspectivă, educaţia este văzută ca sprijinirea elevilor/ studenților/ cursanţilor în a descoperi nevoia lor de cunoaştere, învăţarea fiind reprezentată de dobândirea instrumentelor care să îi ajute pe aceștia să se autorealizeze/actualizeze, să se adapteze la schimbările vieții și ale lumii în care trăim.

Cognitiviştii, spre deosebire de behaviorişti, doresc să reliefeze procesele cognitive din spatele comportamentelor observabile. Pentru ei, învăţarea este stâns legată de calitatea procesărilor cognitive ale persoanei (Amstrong, 2006), accentul căzând pe modul în care informaţiile sunt receptate, organizate, stocate, reactualizate (Miclea, 1999) şi totodată pe gândurile, credinţele sau atitudinile actorilor implicaţi în învăţare (David, 2006). Asemeni behaviorismului, se accentuează importanţa contextului în care are loc învăţarea, însă cognitiviştii subliniază că învăţarea nu poate fi explicată doar de condiţiile de mediu. Din această perspectivă, elevul/studentul/cursantul nu este un individ pasiv în procesul de învăţare, ci o parte activă, căreia dorim să îi dezvoltăm strategii eficiente de receptare și prelucrare a informaţiei. Este de dorit ca profesorul să conştientizeze experienţele diferite de învăţare ale elevilor/studenţilor/cursanţilor şi impactul acestora asupra situaţiei prezente de învăţare, să determine cea mai potrivită modalitate de organizare şi structurare a informaţiilor noi, să împletească aplicabilitatea practică a celor învăţate cu oferirea feedbackului, astfel încât noile informaţii să fie asimilate cât mai eficient şi eficace în structura cognitivă a acestuia (Orey, 2008).

Paradigma socio-cognitivă presupune un determinism reciproc între persoană şi mediu (Wang şi Ling, 2007). Învăţarea este înţeleasă ca o modificare comportamentală, determinată atât de mediul social prin prezenţa interacţiunilor sociale, cât şi de persoana în sine, prin procesările cognitive de informaţie (Amstrong, 2006). Elevul/studentul/cursantul este proactiv şi responsabil pentru învăţare, nu doar reactiv (Opre, 2003). El învaţă un comportament fie prin observarea şi imitarea comportamentelor unui model (aici, de faţă, profesorul), indiferent de întăriri, însă îl practică doar dacă percepe consecinţe pozitive pentru manifestarea comportamentul învăţat (Bandura, în Cervone, Shadel şi Jencius 2009), fie prin condiţionare vicariantă (empatizarea cu modelul). Profesorul are rolul central de a dezvolta autoeficacitatea percepută a elevilor/studenților/cursanţilor, fiind în acelaşi timp, un model, pentru elevii/studenții săi.

Constructivismul porneşte de la asumpţia potivit căreia elevii/ studenții/ cursanții construiesc propria perspectivă asupra lumii. Ca plus valoare adusă perspectivei cognitiviste, constructivismul consideră cursantul 
mai mult decât un procesor activ de informaţie, îl vede un creator de semnificaţii (Orey, 2008). Învăţarea nu presupune asimilarea de cunoştinţe separate, ci elaborarea, interpretarea şi utilizarea flexibilă a acestor cunoştinţe în practică (Spiro, Feltovich, Jacobson, şi Coulson, 1991). Din această perspectivă, această paradigmă se împleteşte cu asumpţiile paradigmei predării centrate pe elev. Rolul profesorului este acela de a instrui cursanţii în construirea de semnificaţii şi în proiectarea de experienţe autentice potrivit nevoilor şi posibilităţilor de învăţare ale lor, pentru a se produce transferul cunoştinţelor şi abilităţilor dobândite la noi contexte. Putem spune că accentul cade pe capacitatea elevului / studentului / cursantului de control şi manipularea informaţiilor, pe necesitatea prezentării informaţiei în multiple modalităţi, pe proiectarea sarcinilor de rezolvare de probleme, pentru exersarea aplicabilităţii noilor cunoştinţe şi evaluare învăţării în termeni de transfer (Ertmer şi Newby, 1993). Aici, rolul profesorului este la fel de important ca cel al elevului / studentului / cursantului, învăţarea fiind centrată pe elev/student/cursant.

Datorită faptului că practicile educaţionale sunt supuse continuu schimbării, datorită dezvoltării tehnologiei informaţiei, producerii unei cantităţi uriaşe de cunoştinţe şi a cerinţelor tot mai complexe de adaptare la mediul în care trăim, specialiştii care elaborează politicile educaţionale ghidate, în prezent, de asumpţiile paradigmei constructiviste, se întreabă, cât de actuală este această paradigmă și dacă nu cumva se impune o trecere la un nou cadru de analiză a învăţării -constructivismul social.

Această nouă abordare defineşte învăţarea ca rezultatul participării active a elevului/studentului/cursantului într-o comunitate - grup, unde sunt construite noi semnificaţii, ca rezultat al consensului participanţilor la experienţa de învăţare (Brown, 2005). În această nouă paradigmă, învăţarea înseamnă dezvoltarea capacităţii de evaluare, de navigare prin multitudinea de baze de date informaţionale accesibile şi integrarea acestor informaţii cu scopul de a rezolva potenţialele probleme de viaţă, susţine acelaşi autor. Aici, profesorul este antrenorul abilităţilor şi competenţelor necesare de navigare în marea de informaţii accesibilă acestora.

Paradigmele învăţării au servit ca bază pentru dezvoltarea unor cadre de lecturare a relaţiei cadru didactic - elev/student. Astfel, literatura de specialitate din ultimii ani, subliniază rolul major pe care îl are elevul/studentul, în cazul nostru, chiar și cursantul, respectiv, formabilul înscris la cursurile de formare, în procesul de învăţare (Ertmer şi Newby, 1993, Brown, 2005; Orey, 2008). Dacă iniţial, accentual cădea pe rolul profesorului, acesta fiind "pionul principal" în procesul de transmitere de cunoştinţe, unic ca sursă de cunoaştere, acum, datorită cantităţii mari de cunoaştere produsă în fiecare moment şi incapacităţii minţii umane de a o deţine pe toată, profesorul este văzut ca un facilitator al învăţării. Obiectivul interacţiunii profesor - elev îl reprezintă optimizarea procesului de învăţare, 
asistarea cursantului în transferarea informaţiilor dobândite în mediile în care are nevoie de ele. Potrivit acestei abordări, nu mai sunt relevante doar cunoştinţele şi expertiza profesorului într-un anumit domeniu, ci şi calităţile sale personale (ex: trăsăturile de personalitate, valorizarea punctelor tari ale elevului / studentului / cursantului şi a stilurilor personale de învăţare) implicate în construirea relaţiei de parteneriat profesor - elev / student / cursant.

După definirea învăţării, a rolului profesorului şi cursantului / formabilului în paradigmele prezentate mai sus, ne vom îndrepta atenţia asupra modului în care literatura de specialitate prezintă conceptele de formare profesională, formator, eficienţa unui program de formare profesională, personalitate, cunoştinţe.

Formarea profesională, în accepţiunea cea mai simplă, presupune dezvoltarea competenţelor necesare unui individ pentru obţinerea unei bune performanţe în muncă. În cercetările consacrate acestui domeniu, întâlnim, atât termenul de formare profesională, cât şi cel de instruire profesională (Pitariu, 2006). Majoritatea autorilor şi lucrărilor parcurse definesc această activitate de formare/instruire foarte apropiat de definiţia pe care ne-o oferă unul dintre părinţii acestui domeniu, cel care susţine că instruirea profesională este o achiziţionare sistematică de abilităţi, reguli, concepte sau atitudini care duc la îmbunătăţirea performanţei într-un alt mediu de lucru (Goldstein, I.L. şi Ford, J.K., 2002).

Unii autori consideră că învăţarea şi formarea profesională se află în registre diferite. Astfel, Amstrong (2006) arată cum învăţarea are în vedere procesul, iar formarea conţinutul învăţării (planificarea cursului, deciderea asupra metodelor de utilizat). Sloman (2003) susţine că învățarea se referă mai ales la nivelul individual, iar formarea la cel organizaţional. Astăzi, aceste abordări care separă învăţarea de formarea profesională sunt învechite. Accentul cade pe unicitatea fiecărui individ inclus în procesul de învăţare/formare (fie la nivel individual, fie organizaţional) şi pe eficientizarea modului în care cursantul înţelege şi operează cu informaţiile /sursele de informaţie prezentate. Programele de formare profesională care se preocupă mai mult de conţinut, fără a lua în calcul întregul proces al învăţării nu sunt la fel de eficiente ca cele care iau în considerare aceste aspecte.

Reflectând la cele de mai sus, putem spune că în contextul cerinţelor actuale ale unui act educaţional de calitate, indiferent dacă este vorba despre învăţare în clasa de elevi sau de formarea profesională a angajaţilor unei companii, rolul profesorului sau al formatorului se pliază foarte bine pe punctele centrale ale paradigmei constructivismului social, enunţate mai sus. Este relevant ca profesorul sau formatorul să aibă rolul de facilitator al învăţării, să conducă elevul/studentul/cursantul spre dobândirea de competenţe şi spre transferarea lor în contexte de viaţă, reale. 
Literatura de specialitate nu prezintă clar diferenţele dintre cele două categorii de profesionişti: profesor versus formator. Se precizează doar că aşa cum profilul formatorului poate să aibă un impact important asupra eficienţei unui program de formare profesională, la fel şi modul în care este perceptut profesorul poate afecta calitatea actului educaţional (Towler şi Dipboye, 2006). Autorii, anterior menţionaţi, arată cum reputaţia formatorului, împreună cu nevoia de informaţie a participanţilor la un astfel de program de formare profesională pot să influenţeze rezultatele formării. Mai mult decât atât, aceeaşi autori observă că problema profilului optim al formatorului nu este suficient de dezbătută şi analizată, însă nu spun nimic despre posibilele cauze ale omiterii acestei problematici din sfera de cercetare actuală. Probabil că o posibilă explicaţie este dată de faptul că noi, cercetătorii, alegem de cele mai multe ori subiecte de cercetare pentru care avem acces la o bază teoretică generoasă, la paradigme de cercetare, la teorii şi modele explicative. Destul de rar ne alegem să investigăm un subiect despre care nu s-a publicat prea mult, cu toate că acesta este unul dintre dezideratele cercetării ştiinţifice. Acest lucru se datorează, probabil şi faptului că nu dorim să ne asumăm niciun risc în a atinge cerinţa de a publica în reviste de specialitate teze susţinute de teorii consacrate.

Dacă literatura apărută în Statele Unite ale Americii (în baze de date precum: APA, JSTORE, SAGEPUB, EBSQO, etc.) nu tratează foarte clar diferenţele dintre profesor şi formator, analizarea standardelor ocupaţionale elaborate pentru cele două ocupaţii (formator şi profesor) şi publicate pe site-ul oficial al Colegiului Naţional de Formare Profesională a Adulţilor (www.cnfpa.ro), arată că, deşi cuprinse în cadrul aceluiaşi domeniu, Educaţie şi formare profesională, cercetare-proiectare, sport, competenţele prevăzute pentru cele două ocupaţii sunt oarecum diferite. Astfel, profesorul (de gimnaziu şi liceu) este văzut ca fiind cadrul didactic care se adreseazã elevilor cu vârsta între 10 şi 18 ani. Acesta este un individ adaptabil, flexibil, cu dorinţa şi abilitatea de a continua să înveţe şi după terminarea studiilor, pe tot parcursul vieţii, tolerant faţă de opinii diferite. Ca domenii de competenţă pentru profesor, standardul ocupaţional elaborat în 1999 prevede: comunicare, curriculum, dezvoltarea profesională, evaluare, formare elevi, dezvoltare relaţie şcoală - familie - societate. Formatorul este văzut ca specialistul în formare care proiectează, derulează, evaluează şi revizuieşte activităţi teoretice/ practice şi/sau programe de formare şi dezvoltare a competenţelor profesionale, derulate în instituţii specializate sau la locul de muncă. Este necesar să precizăm că publicul ţintă este reprezentat de cele mai multe ori de adulţi, însă acest lucru nu este neapărat. Standardul ocupaţional mai recent dezvoltat pentru formator (2007) prezintă următoarele competenţe ca fiind necesare desfăşurării cu succes a activităţii: pregătirea formării, realizarea activităţilor de formare, evaluarea participanţilor la formare, aplicarea metodelor şi tehnicilor speciale de 
formare. Dacă ne propunem să comparăm cele două definiţii şi profilul de competenţe cheie cerut fiecărei profesii în parte, putem sublinia câteva întrepătrunderi, precum: proiectarea curriculumului/realizarea activităţilor de formare, formarea elevilor/realizarea activităţilor de formare, evaluarea elevilor/evaluarea participanţilor la formare. Chiar dacă restul competenţelor prevăzute nu sunt comune, ele pot fi transferate de la profesor la formator sau invers. Astfel, ambii au nevoie de o comunicare eficientă, de dezvoltare profesională continuă, de întărirea unei relaţii dezirabile între şcoală familie - societate, respectiv, curs de formare profesională - organizaţie societate. Dacă interpretăm aceste caracteristici, putem concluziona faptul că atât profesorul, cât şi formatorul, asemeni asumpţiilor paradigmei constructiviste, au rolul de a instrui cursanţii, astfel încât să asigure producerea transferului de cunoştinţe şi abilităţi la noi contexte din viaţa de familie/ organizaţie sau societate.

Mai nou, studiile din domeniul psihologiei şcolare/educaţionale arată că nu este suficient să investigăm doar variabile precum: formarea iniţială a cadrelor didactice, nivelul cunoştinţelor în domeniul materiei predate sau al cunoştinţ̧elor pedagogice, fiind necesară şi înţelegerea factorilor de personalitate care fac diferenţa între un profesor mediu şi unul bun sau chiar excelent. Relevanţa este şi mai ridicată în domeniul studiului întreprins, deoarece niciun beneficiar nu dorește să plătească pentru un curs dezvoltat şi implementat de un formator mediocru. În acest sens, parcurgerea literaturii recente, arată că o bază de date care poate să reprezinte un input valoros este reprezentată de studiile din domeniul psihologiei educaţionale. Studiile anterioare publicate în reviste cu orientare educaţională au reliefat impactul profilului profesorului asupra performanţelor academice ale elevilor (Murray, Rushton şi Paunonen, 1990; Furnham şi Premuzic, 2005; Malikov, 2005-2006; Arnon şi Reichel, 2007), în ciuda definiţiilor multiple ale personalităţii (aspiraţii, stil cognitiv, dispoziţii, obiective, instincte, interese, motive, nevoi, planuri, năzuinţe, sentimente, trăsături, tipuri, valori ale unei persoane, etc., aşa cum le prezintă Craig, 2005) sau multiplelor moduri de evaluare a acesteia, încă neclare.

\section{Analiza și interpretarea studiilor existente}

În continuare, vom analiza, în ordine cronologică, studiile conduse de autorii mai sus menţionaţi, pentru evidenţierea unor concluzii cu privire la factorii determinanţi ai profilului optim al profesorului.

Primul articol al lui Murray şi colab. (1990) evaluează asocierea dintre 29 trăsături de personalitate şi eficienţa profesională a 46 profesori de psihologie, responsabili cu predarea a 6 tipuri diferite de cursuri. Autorii susţin că, datorită faptului că predarea este în parte un proces social şi interpersonal, pare rezonabil ca trăsăturile de personalitate ale profesorilor să coreleze cu eficienţa acestora în predare. După prelucrarea statistică a 
datelor culese prin intermediul unui chestionar, în alcătuirea căruia au intrat 29 de itemi (trăsături de personalitate), au putut fi extrase, trei mari concluzii. Prima concluzie, arată că perceperea eficienţei în predare variază substanţial, în funcţie de tipul de curs, chiar la acelaşi profesor. Apoi, a doua concluzie, spune că evaluările studenţilor, relative la profilul de personalitate al profesorilor, sunt foarte asemănătoare cu evaluările colegilor profesorilor evaluaţi. A treia concluzie, arată cum combinaţii diferite de trăsături de personalizate ale profesorului eficient, variază substanţial în funcţie de tipul de curs predat. Astfel, foarte puţini profesori vor avea trăsăturile de personalitate necesare pentru a fi buni în predarea mai multor tipuri de cursuri, mai ales, dacă acestea sunt mai puţin asemănătoare între ele. Totuşi, trăsături de personalitate, precum leadership-ul şi flexibilitatea au fost identificate ca fiind asociate cu eficienţa generalizată în predare. Conducerea unei analize factoriale pe setul de date culese, a reliefat gruparea celor 29 de trăsături de personalitate în 5 caracteristici supraordonate: extraversiunea, dorinţa de realizare, afectivitate negativă, flexibilitate şi neuroticism, fiecare clasă sau diferite combinaţii de clase fiind asociate cu eficienţa în predare, în funcţie de tipul de curs (ex: cursurile introductive şi generale presupun scoruri mari la extraversiune, dar scoruri mici la afectivitate negativă).

Păstrând aceeaşi direcţie de focalizare pe trăsăturile de personalitate ale profesorului, un alt studiu condus de Furnham şi Premuzic (2005) examinează relaţia dintre personalitatea studenţilor, inteligenţa lor (aici ca inteligenţă fluidă) şi preferinţa pentru un anumit profil de personalitate al profesorului. Ca imagine de ansamblu, studenţii tind să prefere profesori stabili emoţionali, deschişi şi conştiincioşi, aceste caracteristici fiind oglinda trăsăturilor de personalitate autopercepute de respondenţi. Statistica descriptivă evidenţiază ca fiind considerate cele mai importante/dezirabile trăsături de personalitate ale unui dascăl: sociabilitatea, inteligenţa, leadership-ul, oferirea de susţinere elevilor şi flexibilitate în abordarea disciplinei predate. Scorurile cele mai mici au fost înregistrate de: atitudinea de apărare în faţa provocărilor, anxietate, neuroticism. Studenţii extraverţi şi deschişi preferă cadrele didactice stabile emoţional şi deschise. Agreabilitatea şi conştiinciozitatea la studenţi sunt predictori pentru dorinţa de agreabilitate la cadrului didactic. Autorii mai evidenţiază o corelaţie inversă, semnificativă între inteligenţa fluidă a studenţilor şi preferinţa lor pentru neuroticismul profesorului. Analiza de regresie arată că preferinţa pentru profesorii agreabili este prezisă de studenţii care se caracterizează ca fiind mai puţin inteligenţi, dar agreabili şi introverţi. Studenţii inteligenţi preferă profesorii asertivi, motivaţi de argumentare şi dicuţii combative.

Malikov (2005-2006) conduce un studiu cu scopul de a evidenţia factorii care influenţează eficienţa cadrelor didactice. În acest sens, autorul, pornind de la definiţia eficienţei cadrului didactic definită ca "abilitatea de a 
trece mai departe de atingerea rezultatelor dorite" (pag. 1), a chestionat 316 elevi ai Colegiului Le Moyane pentru a reliefa cele mai frecvente dimensiuni de personalitate subsumate definiţiei de mai sus. Acestea au fost: stimularea elevilor, provocarea lor, simţul umorului, entuziasmul, creativitatea, grija faţă de elevi şi capacitatea de a explica materiale de învăţare complicate pe înţelesul tuturor.

Ultimul studiu analizat pe această temă îşi focalizează atenţia pe imaginea profesorului ideal în relaţie cu imaginea de sine, în rolul de profesor. Arnon şi Rachel (2007) investighează categoriile care contribuie la construirea profilului optim al unui cadrul didactic, reliefând ca fiind relevante trăsături de personalitate şi baza de cunoştinţe (de specialitate şi pedagogice) deţinute de acesta. Din punctul lor de vedere, profesorul ideal este "cineva care are cunoştinţe academice, ale cărui obiective implică o misiune socială, care se focalizează pe dezvoltarea individului şi a gândirii critice şi a cărui personalitate stă în mijlocul activităţii de predare" (pag. 448). Rezultatele studiului arată o tendinţă a respondenţilor mai tineri şi fără experienţă în predare de a considera personalitatea profesorului ca fiind dominantă, în timp ce tinerii profesori acordă o importanţă mai mare cunoştinţelor. Sunt importante atât personalitatea, cât şi baza de cunoştinţe a profesorului. $\mathrm{Cu}$ cât creşte experienţa respondenţilor în domeniul predării, cu atât respondenţii consideră mai valoroasă baza de cunoştinţe. Toţi subiecţii interogaţi oferă ca descriere a profilului de personalitate al profesorului aceleaşi trăsături de personalitate sau trăsături similare celor care intră în alcătuirea profilului lor de personalitate (aşa cum se autopercep). De exemplu, studenţii care urmează să devină profesori şi se descriu ca având trăsături de personalitate, precum empatia şi grija faţă de ceilalţi, transferă aceste trăsături şi la profilul de personalitate al profesorului ideal. Autorii oferă şi o posibilă explicaţie pentru acest transfer. Ei admit că această conştientizare a unui nivel scăzut de cunostinţe în domeniul predării şi în domeniul pedagogic să determine disonanţă cognitivă, iar pentru reducerea tensiunii, respondenţii să plaseze această componentă a profilului optim al profesorului, pe plan secund.

Trecerea în revistă a acestor studii arată cât de important este pentru actul educaţional în sine, reliefarea profilului optim al cadrului didactic. Transferând acest tip de abordare asupra subiectului de interes din lucrarea de faţă, ne propunem să identificăm care sunt caracteristicile dezirabile la un formator. $\mathrm{Nu}$ ne vom opri atenţia doar asupra caracteristicilor de personalitate, ci vom încerca să identificam şi alţi factori definitorii pentru profilul optim al unui formator. De ce facem acest lucru? Deoarece, unii autori menţionaţi anterior subliniază rolul major şi al altor variabile care alcătuiesc profilul cadrului didactic în atingerea obiectivelor instrucţionale propuse. Un exemplu, în acest sens, este dat de baza de cunoştinţe pe care trebuie să le deţină un profesor/formator pentru a fi eficient. Ce sunt aceste 
cunoştinţe? Cum pot să fie ele definite? Cunoştinţele sunt înţelese ca expertiză dobândită de către o persoană prin experienţă sau educaţie sau ca înţelegere teoretică sau practică a unui subiect (Soanes, 2006).

În ceea ce priveşte posibilităţile de cercetare ale profilului optim al formatorului, literatura de specialitate ne pune la dispoziţie mai multe metode posibile de analiză. Astfel, Băban (2002) include într-una dintre lucrările sale ca posibile lentile de studiu, mai multe metode de cercetare calitativă precum: analiza fenomenologic interpretativă, analiza de conţinut, analiza tematică, analiza narativă, analiza de discurs, teoria generată şi metoda acţiune-cercetare. Cum se caracterizează acestea şi care dintre acestea se pliază cel mai bine pe scopul cercetării de faţă, vom analiza în cele ce urmează.

Analiza fenomenologic interpretativă presupune surprinderea perspectivei respondenţilor (aici, a beneficiarilor cursurilor de formare profesională, a formatorilor cu experienţă şi a celor fără experienţă) asupra formării profesionale. Această metodă de culegere a datelor poate fi utilizată indiferent de paradigma în care ne conducem cercetarea, obiectivul principal fiind identificarea unor teme care rezultă din analiza răspunsurilor oferite de respondenţi (aici, sub forma caracteristicilor profilului optim al formatorului).

Analiza de conţinut este o altă metodă de cercetare calitativă în a cărei sferă de interes se află conţinutul mesajelor (verbale, scrise sau vizuale) (Băban, 2002). În acest sens, analizarea materialului de interes presupune: alegerea unei unităţi de analiză (cuvânt, fraza, etc), reliefarea unor categorii (10-15), stabilirea modului în care aceste categorii se interrelaţionează unele cu altele şi determinarea unor indici cantitativi cu privire la aceste categorii / unităţi de conţinut (frecvenţă, poziţionarea în spaţiu, formă, intensitate, etc), aşa cum arată Graneheim şi Lundman (2004). În codare se pierd cuvintele respondenţilor şi rămân categoriile în care acestea pot fi reunite. Acest tip de analiză a datelor este potrivită atunci când cercetătorul doreşte să evidenţieze o imagine de ansamblu asupra fenomenului investigat exprimată în indici cantitativi (ex: $24 \%$ dintre formatorii cu experienţă consideră importante cunoştinţele formatorului în domeniul temei cursului susţinut). În cazul cercetării propuse de noi, analiza de conţinut ne permite identificare frecvenţei caracteristicilor care alcătuiesc profilul de personalitate al formatorului ideal, dar nu şi modul de relaţionare al acestor caracteristici.

Analiza tematică este o altă metodă de culegere de date, însă destul de slab delimitată şi rareori recunoscută ca metodă de cercetare (Braun şi Clarke, 2006). Această metodă presupune analizarea mai multor interviuri cu scopul de a reliefa un fir /o temă comună care apare între acestea ca o punte de legătură. Metoda presupune mai întâi citirea şi recitirea interviurilor, apoi descoperirea a cât mai multor teme de interes posibile, stabilirea legăturilor între acestea pentru o supraordonare a lor şi o comasare 
a subcategoriilor în categorii principale, pentru ca în final să ajungem la reliefarea unei imagini de ansamblu asupra fenomenului investigat (Fereday şi Muir-Cochrane, 2006).

Analiza narativă are ca scop analizarea modului organizat în care noi dăm sens şi predictibilitate vieţii. Utilitatea principală care reiese din utilizarea acestei metode este cea terapeutică. Studiul naraţiunilor se dovedeşte potrivit mai ales pentru experienţa bolii (Băban, 2002; Jordens, Little, Paul, şi Sayers, 2001), iar costul principal al adoptării unei astfel de metode îl reprezintă timpul foarte lung de intervievare (3-8 ore/interviu, arată Squire, 2005).

Analiza de discurs presupune analiza rolului activ şi constructiv al limbajului, într-un context social dat (Hodges, Kuper, Reeves, 2008). Asumpţia de bază a acestei perspective presupune că individul este diferit, în funcţie de context (Băban, 2002), accentul căzând pe căutarea de semnificaţii date fenomenului/temei investigate, prin analizarea cuvintelor, pauzelor din discurs, intonaţiilor. Există mai multe forme de analiză de discurs: formal - lingvistică (presupune descoperirea regulilor care stau la baza comunicării, microanaliză la nivel lingvistic, semantic şi gramatical), critică (presupune reliefarea modul în care discursurile construiesc versiuni ale lumii sociale) şi empirică (o macroanaliză a modului în care discursurile construiesc ceea ce este posibil pentru individ). Niciuna dintre aceste variante nu se pliază pe obiectivul de cercetare enunţat mai sus, cu toate că apreciem validitatea ecologică ridicată a acestei metode. Deoarece analiza de discurs este centrată pe discursul avut într-un anumit context, nu putem desprinde o imagine generală asupra fenomenului investigat, aici părerile respondenţilor cu privire la profilul optim al formatorului în general. Mai mult decât atât, nu suntem interesaţi de detaliile conversaţiei sau de influenţa contextului asupra răspunsurilor date de subiecţi, deoarece, din motive de timp nu vom conduce interviuri cu aceştia. Este un proces mult prea laborios pentru scopul cercetării noastre.

Teoria generată este una dintre cele mai creative metode de cercetare prezentate în literatura de specialitate. Scopul principal al acestei metode, descrise iniţial de Glaser şi Straus (în Băban, 2002) îl reprezintă generarea de teorii despre fenomele sociale întâlnite (Lingard, Albert, Levinson, 2008) şi nu testarea de ipoteze. Cercetătorul caută să înţeleagă situaţia cercetată, de accea coroborează mai multe metode de cercetare (ex: observaţia, interviul) şi compară constant datele culese, identificând categorii şi sub-categorii în care acestea pot fi grupate, eventuale legături între acestea, pentru ca în final să formuleze o teorie explicativă pentru fenomenul investigat. În demersul de cercetare propus de noi dorim să testăm dacă ceea ce ne prezintă literatura de specialitate apare ca fiind relevant în determinarea profilului optim al formatorului. Nu dorim să dezvoltăm o nouă teorie, ci să demonstrăm că este potrivit un transfer al 
modelului explicativ al profesorului eficient, în cazul formatorului. În acest sens, trebuie doar să identificăm factorii comuni şi relevanţi ai profilului optim al formatorului şi gradul lor de potrivire cu rezultalele studiilor anterioare care au investigat profilul optim al profesorului.

$\mathrm{Nu}$ în ultimul rând, supunem analizei, metoda acţiune cercetare - care presupune ca etapele de culegere a datelor să se împletească cu cele de implementare de acţiuni sociale care vizează schimbarea fenomenului investigat. Aceste acţiuni vor fi derivate din cercetare, cu scopul de a oferi soluţii unor probleme specifice cu care se confruntă grupul ţintă. Această metodă de cercetare se desfăşoară ciclic (cercetare - implementare schimbare), până la obţinerea efectului dorit. În cazul propunerii de cercetare făcute aici, intervin factori care nu pot fi controlaţi sau condiţii care nu pot fi îndeplite. Nu ne propunem să studiem o anumită organizaţie, comunitate, deci nu vom putea implementa schimbarea, fiindcă nu avem un grup/organizaţie ţintă, în acest sens. Mai mult, această metodă de cercetare presupune o implicare a cercetătorului în viaţa de $\mathrm{zi}$ cu zi a persoanelor/organizaţiei studiate, ceea ce este dificil şi foarte constisitor (ca bani şi timp). Rapiditatea cu care firmele/organizaţiile apar şi dispar în contextul economic actual reduce simţitor posibilitatea conducerii unor cercetări care să se întindă pe o perioadă mai lungă de timp. Prin urmare, această metodă nu poate fi considerată ca o posibilă alternativă pentru analizarea şi interpretarea datelor.

Prin urmare, baleierea literaturii de specialitate care prezintă posibilele lentile prin prisma cărora putem culege date importante pentru subiectul de investigat, în coroborare cu analiza critică a resurselor (materiale - timp, bani, şi umane - accesul la respondenţi, organizaţii) pe care le avem la dispoziţie, ne determină să alegem pentru studiul cercetării, metoda analizei de conţinut ca modalitate de identificare a profilului optim al formatorului.

Pentru prelucrarea datelor cantitative vom utiliza statistica descriptivă.

În concluzie, la studiul pe care îl propunem, vom avea în vedere investigarea percepţiilor a trei categorii de respondenţi cu privire la caracteristicile importante care alcătuiesc profilul optim al formatorului, prin prisma paradigmei constructivismului social. Analizarea răspunsurilor oferite de respondenţi se va face prin intermediul analizei de conţinut, respectiv, a analizei statistice descriptive, cu scopul evidenţierii modelului optim al formatorului şi comparării acestuia cu modelulul optim al profesorului - model anterior prezentat în studiile din domeniul psihologiei educaţionale.

\section{Concluzii}

În urma studierii atente a literaturii de specialitate devine relevant ca profesorul sau formatorul să aibă rolul de facilitator al învăţării, să conducă 
elevul/studentul/cursantul/formabilul spre dobândirea de competenţe şi spre transferarea lor în contexte de viaţă, reale.

\section{Bibliografie}

Amstrong, M.,(2006). A Handbook of Human Resource Management Practice, $10^{\text {th }}$ Edition, Kogan Page, London and Philadelphia;

Băban, A., (2002). Metodologia cercetarii calitative, Ed. Presa Universitară Clujeană, Cluj-Napoca;

Braun, V., şi Clarke, V., (2006). Using thematic analysis in psychology, Qualitative Research in Psychology, 3, 77-101;

Brown, T., (2005). Beyond constructivism: Exploring the future learning paradigms, Education Today, Aries Publishing Company, 1-11;

Cervone, D., Shadel, W., G., şi Jencius, S., (2009). Social-Cognitive Theory of Personality Assessment, Personality and Social Psychology Review, 5, (1) 33-51;

Craig, R.,J., (2005). Assessing Personality and Mood with Adjective Check List Methodology: A Review, International Journal Of Testing, 5(3), 177-196;

David, D., (2006). Psihologie clinică şi psihoterapie; Fundamente. Iaşi, Ed. Polirom, Iaşi;

Ertmer, P. A., şi Newby, T. J., (1993). Behaviorism, cognitivism, constructivism: Comparing critical features from an instructional design perspective, Performance Improvement Quaterly, 6 (4), 73-91;

Fereday, J., şi Muir-Cochrane, E., (2006). Demonstrating Rigor Using Thematic Analysis: A Hybrid Approach of Inductive and Deductive Coding and Theme Development, International Journal of Qualitative Methods, 5 (1), 111 ;

Furnham, A., și Premuzic, T. C., (2005). Individual Differences in Students' Preferences for Lecturers' Personalities, Journal of Individual Differences, 26 (4), 176-184;

Goldstein, I. L., şi Ford, J. K. (2002). Training in organizations (4th edition). Belmont, CA:Wadsworth;

Graneheim, U. H., şi Lundman, B., (2004). Qualitative content analysis in nursing research:

concepts, procedures and measures to achieve trust worthiness, Nurse Education Today, 24, 105-112;

Hodges, B. D., Kuper, A., Reeves, S., (2008). Qualitative Research. Discourse Analysis, $B M J$ (337), 570-577 ;

Jordens, C. F. C., Little, M., Paul, K., şi Sayers, E. J., (2001). Models of narrative analysis: A typology, Journal of Narrative and Life History, 52, 87-123; 
Lingard, L., Albert, M., Levinson, W., (2008). Qualitative Research. Grounded theory, mixed methods, and action research, $B M J(337)$, 459-461;

Malikov, M., (2005-2006). Effective teacher study, National Forum for Teacher Journal - Electornic Volume, 16, (3), 1-9;

Miclea, M., (1999). Psihologie cognitivă. Modele teoretico-experimentale, Editura Polirom, Iaşi;

Murray, H. G., Rushton, J. P., şi Paunonen, S. V., (1990). Teacher Personality Traits and Students Instructional Ratings in Types of University Courses, Journal of Educational Psychology Journal of Educational Psychology, 82, (2), 250-261;

Opre, A., (2003). Introducere în psihologia personalităţii, Editura ASCR, ClujNapoca;

Orey, M., (2008). Comparison of Learning Major Paradigms,

Pitariu, H. D., (2006). Proiectarea fişelor de post, evaluarea posturilor de muncă şi a personalului. Un ghid practic pentru managerii de resurse umane, Editura Irecson, Bucureşti;

Reichel, N., (2007), Who is the ideal teacher? Am I? Similarity and difference in perception of students of education regarding the qualities of a good teacher and of their own qualities as teachers, Teachers and Teaching theory and practice, 13, (5), 441-464;

Sloman, M., (2003). E-learning: stepping up the learning curve, Impact, CIPD, 1617 ;

Soanes, C., (2006). Compact Oxford English Dictionary for Students, Oxford University Press;

Spiro, R. J., Feltovich,P. J., Jacobson, M. J., şi Coulson, R. L., (1991). Cognitive flexibility, constructivism and hypertext: Random access instruction for advanced knowledge acquisition in ill-structered domains, Educational Technology, 31 (5), 24-33;

Towler, A. J., şi Dipboye, R. L., (2001). Effects of trainer expressiveness, organization, and trainee goal orientation on training outcomes. Journal of Applied Psychology, 86, 664-673; 